\title{
Phytoprotection
}

\section{Molecular and cellular aspects of Dutch elm disease}

\section{M.B. Sticklen, M.G. Bolyard, R.K. Hajela et L.C. Dufresne}

Volume 72, numéro 1, 1991

URI : https://id.erudit.org/iderudit/705997ar

DOI : https://doi.org/10.7202/705997ar

Aller au sommaire du numéro

Éditeur(s)

Société de protection des plantes du Québec (SPPQ)l

ISSN

0031-9511 (imprimé)

1710-1603 (numérique)

Découvrir la revue

Citer cet article

Sticklen, M., Bolyard, M., Hajela, R. \& Dufresne, L. (1991). Molecular and cellular aspects of Dutch elm disease. Phytoprotection, 72(1), 1-13.

https://doi.org/10.7202/705997ar

\section{Résumé de l'article}

Cet article de synthèse présente une revue des recherches concernant les interactions moléculaires et cellulaires de la maladie hollandaise de l'orme. Cette maladie, causée par le champignon Ophiostoma ulmi, provoque un flétrissement vasculaire et elle est transmise d'ormes infectés à des ormes sains par des scolytes. Des toxines fongiques sont décrites en relation avec la pathogénèse, l'une d'elles, la cérato-ulmine, étant sous investigation au niveau moléculaire, plus particulièrement en ce qui concerne son mode $d$ 'action et sa localisation. Le champignon a aussi été examiné au niveau moléculaire pour différencier des isolats agressifs et non agressifs sur la base de profils protéiques et d'acides nucléiques. Des cartes de lien génétique sont en développement afin de corréler la perturbation de certains gènes avec la perte du pouvoir pathogène. Des antagonistes viraux et bactériens du champignon, qui peuvent être utilisés comme mécanisme de lutte biologique contre la maladie hollandaise de l'orme, ont été caractérisés ainsi que plusieurs des molécules actives intervenant dans cette lutte. Les réponses de l'hôte sont discutées aux niveaux moléculaire et biochimique, incluant les phy toalexines et les éliciteurs des mécanismes de défense. Plusieurs avenues de recherche sont discutées afin de fournir une revue des approches moléculaires visant à comprendre et à manipuler les organismes impliqués en vue du but ultime de lutter contre la maladie hollandaise de l'orme.
Ce document est protégé par la loi sur le droit d'auteur. L’utilisation des services d’Érudit (y compris la reproduction) est assujettie à sa politique d'utilisation que vous pouvez consulter en ligne.

https://apropos.erudit.org/fr/usagers/politique-dutilisation/ 


\title{
Molecular and cellular aspects of Dutch elm disease
}

\author{
Mariam B. Sticklen'1, Mark G. Bolyard, Ravindra K. Hajela, and Luc C. Duchesne ${ }^{2}$ \\ 202 Pesticide Research Center, Department of Crop and Soil Sciences and Department of Entomology, \\ Michigan State University, East Lansing, Michigan, U.S.A.48824-1311 \\ 1. Author to whom correspondence should be addressed. \\ 2. Current address: Petawawa National Forestry Institute, Chalk River, Ontario, Canada K0J 1JO
}

(Received 1990-11-22; accepted 1991-03-05)

The following review gives an overview of current research in the area of molecular and cellular interactions in Dutch elm disease. This vascular wilt disease is caused by the fungus Ophiostoma ulmi and is transmitted from diseased to healthy trees by the elm bark beetles. Fungal toxins are described which are associated with pathogenesis, one of which, cerato-ulmin, is under investigation at the molecular level, particularly regarding its mode of action and localization. The fungus has also been examined at the molecular level to differentiate between aggressive and nonaggressive isolates on the basis of protein and nucleic acid profiles. Genetic linkage maps are being developed to correlate disruption of certain genes with the loss of pathogenicity. Viral and bacterial antagonists of the fungus, which may serve as biological control mechanisms for Dutch elm disease, have been characterized, as have several of the active molecules responsible for control. Host responses are also discussed at the molecular and biochemical level, including phytoalexins and defense mechanism elicitors. Several lines of investigation are discussed to provide an overview of molecular approaches to understanding and manipulating the organisms involved with the ultimate goal of controlling Dutch elm disease.

Sticklen, M.B., M.G. Bolyard, R.K. Hajela, and L.C. Duchesne. 1991. Molecular and cellular aspects of Dutch elm disease. PHYTOPROTECTION 72: 1-13.

Cet article de synthèse présente une revue des recherches concernant les interactions moléculaires et cellulaires de la maladie hollandaise de l'orme. Cette maladie, causée par le champignon Ophiostoma ulmi, provoque un flétrissement vasculaire et elle est transmise d'ormes infectés à des ormes sains par des scolytes. Des toxines fongiques sont décrites en relation avec la pathogénèse, 1'une d'elles, la cérato-ulmine, étant sous investigation au niveau moléculaire, plus particulièrement en ce qui concerne son mode d'action et sa localisation. Le champignon a aussi été examiné au niveau moléculaire pour différencier des isolats agressifs et non agressifs sur la base de profils protéiques et d'acides nucléiques. Des cartes de lien génétique sont en développement afin de corréler la perturbation de certains gènes avec la perte du pouvoir pathogène. Des antagonistes viraux et bactériens du champignon, qui peuvent être utilisés comme mécanisme de lutte biologique contre la maladie hollandaise de l'orme, ont été caractérisés ainsi que plusieurs des molécules actives intervenant dans cette lutte. Les réponses de l'hôte sont discutées aux niveaux moléculaire et biochimique, incluant les phytoalexines et les éliciteurs des mécanismes de défense. Plusieurs avenues de recherche sont discutées afin de fournir une revue des approches moléculaires visant à comprendre et à manipuler les organismes impliqués en vue du but ultime de lutter contre la maladie hollandaise de l'orme.

\section{Introduction}

In recent years a tremendous effort has been exerted toward understanding the various cellular and molecular aspects of Dutch elm disease (DED). Although this is only one of several important areas of research on DED, excellent review articles on other aspects of DED have recently become available, covering such topics as the control of the elm bark beetles (Scolytus multistriatus Marsham, Scolytus scolytus Fabri., and Hylugropinus

$\overline{0031-9511 / 91 \$ 1.00+.10}$ rufipes Eichoff) (Lanier 1989), biological control strategies for DED (Mazzone and Peacock 1985), host factors (Takai 1989), mechanisms of action of wilt toxins (Van Alfen 1989), resistance mechanisms to Dutch elm disease (Duchesne 1988), and elm tissue culture (Karnosky and Mickler 1986). A wellillustrated description of the life cycle of the causal organism of DED, the toxin-producing ascomycetous fungus Ophiostoma ulmi (Buism.) Nannfeldt, formerly Ceratocystis ulmi (Buism.) C. Moreau as determined by de Hoog and Scheffer (1984), is available elsewhere (Agrios 1988). 
The fungal pathogen is believed to have been brought into North America in the late 1920 's in infected 'green' elm logs used as veneer in the furniture industry (May 1930). Since the introduction of the disease, DED has been responsible for the devastation of the American elm (Ulmus americana L.) and its removal from the urban American and Canadian landscape. The disease is transmitted from diseased to healthy trees via the elm bark beetle. Considerable effort and resources have been channeled into trying to rescue the American elm and other susceptible elm species from total destruction. Despite massive efforts to prevent its spread, DED is now found in many areas of the world and $O$. ulmi is capable of evolving rapidly under environmental pressures (Brasier 1988).

Resistance to DED is associated with compartmentalization of the fungal pathogen (Bonsen et al. 1985; Shigo 1984), evident anatomically as brown longitudinal streaks in the sapwood and microscopically as an occlusion of vessels (Beckman 1971). These occlusions are caused by the formation of tyloses, which are outgrowths of xylem parenchymal cells that protrude through the pits to clog the vessel cavity and prevent the movement of substances to other vascular elements (Beckman 1971). These and other structures formed in response to infection have been studied in fine ultrastructural detail (Ouellette 1978a, 1978b, 1978c). DED-resistant elms are able to quickly and efficiently induce more tyloses than susceptible elms (Elgersma 1973), preventing the spread of $O$. Ulmi by filling xylem vessels (Elgersma and Miller 1977). American elms form tyloses only after periods of high susceptibility to infection (Ouellette 1980) perhaps increasing their vulnerability to DED. However, the timing, chemical trigger, and biochemical pathways involved in tylosis have yet to be determined. Another host response associated with DED and plant diseases in general is an increase in respiration which occurs soon after infection (Landis and Hart 1972; Richards and Takai 1984). This increase is more rapid in resistant plants, possibly to mobilize defense mechanisms that require an expenditure of energy.

Although several means of control or elimination of DED have been used with varying degrees of success, none has managed to control DED effectively (Mazzone and Pea- cock 1985). However, the long-term management of American elm populations dictates the development of resistant elms and/or the establishment of new means of disease control. This stragegy calls for a clear understanding of the molecular biology of the hostvector-pathogen interactions and factors affecting them. In the following section we have attempted to highlight some of the more recent progress made in this direction. However, the molecules involved in Dutch elm disease (Table 1) have been characterized mainly in the pathogen, and to a lesser extent in the host and the beetle vector.

\section{Pathogen}

Fungal metabolites associated with pathogenesis. The toxins produced by $O$. ulmi have come under intense scrutiny because of their controversial role in pathogenesis. Although several toxins have been implicated in DED (Claydon et al. 1980), two of these, each isolated from liquid-shake cultures of $O$. ulmi, have been studied in some detail. The first is cerato-ulmin (CU) (Takai 1974), a hydrophobic $7.6 \mathrm{kDa}$ polypeptide (S. Takai, unpublished data). The second is a high molecular weight peptidorhamnomannan of 105-120 kDa (Strobel et al. 1978).

It was first proposed that $\mathrm{CU}$ is produced specifically by aggressive isolates of $O$. ulmi and is the metabolite responsible for the symptoms of the disease (Takai 1974). The purified toxin was shown to cause the same symptoms as the fungus including wilting, internal vessel anomalies (browning, tylosis, and vessel infarction), and altered membrane permeability causing nonspecific electrolyte loss (Richards and Takai 1984), although this observation is in marked contrast to those observed with most other wilt toxins which act by reducing water availability and hindering transport (Hall and MacHardy 1981; Van Alfen 1989). Cerato-ulmin was detected only in aggressive strains of $O$. ulmi when electron microscopic observations were made on immunocytochemically prepared material (Svircev et al. 1988). The toxin is proposed to be host specific (S. Takai, unpublished data) as is the fungus (Takai 1974), although the examination of the effects of the fungus on nonhost plants has provided some insight as to the prevention of the perpetuation of the disease 
Table 1. Molecules associated with Dutch elm disease

\begin{tabular}{|c|c|c|c|}
\hline Organism & Molecule & Characteristic & Reference \\
\hline \multirow[t]{4}{*}{ Fungus } & Cerato-ulmin & $\begin{array}{l}\text { Toxin, responsible for } \\
\text { some DED symptoms }\end{array}$ & $\begin{array}{l}\text { Nordin et al. } 1987 \\
\text { Richards and Takai 1984; } \\
\text { Takai } 1974\end{array}$ \\
\hline & Peptidorhamnomannan & $\begin{array}{l}\text { Toxin, causes } \\
\text { some DED symptoms }\end{array}$ & Strobel et al. 1978 \\
\hline & $\begin{array}{l}\text { Other high molecular } \\
\text { weight glycoproteins }\end{array}$ & $\begin{array}{l}\text { Toxins, result in several } \\
\text { DED symptoms }\end{array}$ & $\begin{array}{l}\text { Scheffer } \text { et al. } 1987 \\
\text { Strobel et al. } 1978\end{array}$ \\
\hline & Elicitors & $\begin{array}{l}\text { Fungal glycoproteins } \\
\text { that stimulate } \\
\text { mansonone production } \\
\text { by the host elms }\end{array}$ & Yang et al. 1989 \\
\hline \multirow[t]{3}{*}{ Host } & Mansonones & $\begin{array}{l}\text { Phytoalexins, mansonones } \\
\mathrm{A}, \mathrm{C}, \mathrm{D}, \mathrm{E}, \mathrm{F} \text { and } \mathrm{G} \\
\text { (mansonone E seems to } \\
\text { be associated with DED } \\
\text { resistance or tolerance) }\end{array}$ & $\begin{array}{l}\text { Duchesne et al. } 1984, \\
1985,1990 \\
\text { Dumas etal. } 1983,1986 \\
\text { Jeng et al. } 1983\end{array}$ \\
\hline & Amino acids & $\begin{array}{l}\text { Some amino acid } \\
\text { concentrations increase } \\
\text { in response to infection }\end{array}$ & $\begin{array}{l}\text { Singh and Smalley } 1969 a, \\
1969 b\end{array}$ \\
\hline & Beetle attractants & $\begin{array}{l}\text { Volatiles that attract the } \\
\text { beetles, e.g. }(-)-\alpha \text {-cubebene }\end{array}$ & Lanier 1983 \\
\hline Beetle & Pheromones & $\begin{array}{l}\text { Beetle sex hormones } \\
\text { that attract other } \\
\text { beetles, e.g. }(-)-\alpha \text {-multistriatin }\end{array}$ & Pearce et al. 1975 \\
\hline
\end{tabular}

in non-host and resistant plants (Rioux and Ouellette 1989). These investigators utilized a variety of non-host plants to observe such mechanisms of resistance as the initiation of physical barriers and the production of phytoalexins.

Cerato-ulmin is very unusual because of its extreme hydrophobicity and surfactant-like properties. This polypeptide is released by the fungus into culture media and appears to be soluble in $70 \%$ ethanol or in chaotropic agents such as concentrated urea. There is a direct correlation between the turbidity of the toxin in suspension and the toxicity of that suspension (Takai et al. 1983). Antiserum has been raised against this purified material (Richards and Takai 1984) and recently an ELISA assay has been developed to more accurately measure the amount of CU present in infected tissues (Nordin et al. 1987).

The hydrophobicity of the peptide has prevented an assessment of the activity of peptide fragments generated by enzymatic digestion or chemical cleavage (Stevenson and Takai 1982). However, it was determined that reduction and carboxymethylation of the disulphide bonds in CU eliminates the toxicity as well as the insolubility of the peptide (Stevenson et al. 1979). Reduction and denaturation of CU followed by dialysis against water also yields a soluble CU peptide, and the toxicity of the reduced and denatured peptide is under investigation (Bolyard and Sticklen 1990). These experiments indicate that some or all of the four intrachain disulphide bonds of CU play a major role in maintaining its activity. The amino acid sequence of the toxin has recently been obtained (M. Yaguchi, unpublished data), but only a portion of the sequence has been published (Stevenson and Takai 1982).

Scheffer and his colleagues were unable to find a strong correlation between aggressiveness of $O$. ulmi isolates and $\mathrm{CU}$ production in that lower levels of CU are produced in certain aggressive strains when compared to nonaggressive strains (Scheffer et al. 1987). It was also suggested that future tests in which the fungus is applied to seedlings should be conducted on elm species other than American elm because of the extent of the damage 
caused even by non-aggressive strains of $O$. ulmi to this species (Scheffer et al. 1987).

Other investigators (Nordin and Strobel 1981; Scheffer 1982; Scheffer and Elgersma 1981; Scheffer et al. 1987; Strobel et al. 1978) have characterized a high-molecular weight glycoprotein which shows some capacity to cause wilting in leaves and a decrease in fluid conductance (Strobel et al . 1987). The molecule is thought to be composed mainly of carbohydrate moieties while the protein portion of the molecule has an apparent molecular weight of only $35 \mathrm{kDa}$ (Nordin and Strobel 1981). This glycoprotein also has not been conclusively correlated with aggressiveness and in fact, a combination of factors may play a role in pathogenicity and aggressiveness (Scheffer etal. 1987). No specific mechanism of action has been proposed for this larger toxin although immunofluorescent staining of infected elms using antisera raised against the glycoprotein was detected in the fungal cell walls (Scheffer et al. 1987). The toxin was not present in the elm tissue itself in these studies (Scheffer et al. 1987), but immunoelectron microscopy determined that the glycopeptide was associated specifically with infected elm cell membranes (Benhamou $e t$ al. 1985; Ipsen and Abul-Hajj 1982).

Antagonists. Naturally occurring antagonists of O. ulmi exist which may provide a limited measure of biological control over the fungal pathogen. The d-factors (Brasier 1983, 1986; Hoch et al. 1985; Rogers et al. 1986b) are mycovirus-like entities (Webber 1987, 1988), one of which, the $\mathrm{d}^{2}$ factor, has been associated with reduced vigor in infected isolates of $O$. ulmi. The d-factors were first described as a set of double-stranded RNAs (dsRNA) observed in afflicted $O$. ulmi isolates (Pusey and Wilson 1982). Although the presence of dsRNA is often associated with viral infections in other disease states (Brasier 1986), no viral particles have been observed in $\mathrm{d}^{2}$-infected O. ulmi (Rogers et al. 1987). The $\mathrm{d}^{2}$-factor transcribes $10 \mathrm{dsRNA}$ species of different sizes which co-purify with mitochondria of affected isolates (Rogers et al. 1986a). The presence of specific dsRNA segments of $2.4,1.0$, and $0.33 \mathrm{~kb}$ are correlated with the disease in the fungus (Rogers et al. 1987) and it may eventually be possible to assign responsibility for the symptoms to specific dsRNA molecules.
The mechanism of action of these molecules is not known and they appear to be a novel class of autonomously replicating elements (Rogers et al. 1987). The presence of the $\mathrm{d}^{2}$-factor has also been correlated with a reduction of the steady-state levels of cytochrome aa $a_{3}$, an important enzyme in the respiratory chain of the fungus, when compared to the levels of two other cytochromes (Brasier 1986). This manifestation could explain the reduction in vigor observed in diseased fungi, which may survive by turning on an alternative respiratory pathway, bypassing the need for cytochrome aa ${ }_{3}$ (Sherald and Sisler 1972). Populations of $\mathrm{d}^{2}$-infected $O$. ulmi have been characterized by a marked reduction in spore germination, a reduction in growth rate, and an inability to initiate xylem infection (Webber 1987).

The d-factors are transmitted from diseased to healty isolates by hyphal fusion or through sexual crossing in the case of compatible mating types (Brasier 1986). Other mechanisms, such as strain-specific replication, may be involved in the interaction between $O$. ulmi and the d-factors that are responsible for the maintenance of these elements (Rogers et al. $1986 \mathrm{~b})$ because the $\mathrm{d}^{2}$-factor can be transferred to other individuals through hyphal fusion or mating, yet they have not become widespread within the population.

Other antagonists of $O . u l m i$ have also been detected, such as the antimycotic properties of certain strains of Pseudomonas syringae van Hall. These experiments demonstrated that certain $P$. syringae strains provided protection to susceptible elm seedlings when administered prior to infection with $O$. ulmi (Lam et al. 1987). Recently an antibiotic, pseudomycin, has been purified from $P$. syringae and its antimycotic property demonstrated on O. ulmi (Harrison 1989). The protective effect of $P$. syringae toward susceptible elms in the greenhouse was demonstrated using genetically-tagged bacteria (Fox 1987; Roberts 1987). Scheffer conducted field trials in the Netherlands and observed a 22$45 \%$ reduction in DED incidence in susceptible elms injected with $P$. syringae (Scheffer 1989).

Inoculations of American elm seedlings with antagonistic isolates of Pseudomonas fluorescens Migula (Murdoch et al. 1984) or 
Bacillus subtilis (Ehrenberg) Cohn (Gregory et al. 1984) and in vitro assays with Bacillus subtilis (Krause et al. 1987) Pseudomonas maltophilia Hugh and Ryschenkow (Gregory et al. 1986) or the fungus Ustilago violacea (Persoon) Roussel (Desrochers et al. 1987), have demonstrated a wide variety of antifungal activity. The antimycotic agents from several of these organisms are being purified for further investigation. However, in studies involving the injection of a variety of bacteria into the DED-susceptible English elm (Ulmus procera Salisb.) and Commelin elm (Ulmus $x$ hollandica 'Commelin'), Shi and Brasier (1986) concluded that none of the strains tested, including several strains shown to be antagonistic in vitro, prevented the death of trees inoculated with $O$. ulmi four weeks after infection with the bacteria. Pretreatment of susceptible elms with non-aggressive strains of $O$. ulmi induced cross-protection against aggressive strains (Jeng et al. 1983; Scheffer et al. 1980). Further investigation will be necessary to determine whether the protective effect of these antagonists can be observed in vivo.

Molecular characterization and detection. Ophiostoma ulmi has been shown to have the potential for rapid evolution as demonstrated by the replacement of the nonaggressive populations of the fungus by more aggressive isolates (Brasier 1988) and by the analysis of its nuclear genome (L.C. Duchesne et al., unpublished data).O. ulmi population has both aggressive and non-aggressive isolates, and considerable effort has gone into developing morphologic and biochemical methods to distinguish between these groups. Early assays correlated differences in culture morphology such as appearance and texture (Brasier and Gibbs 1975; Gibbs and Brasier 1973; Schreiber and Townsend 1976), and growth rate (Brasier and Webber 1987), with aggressiveness, pathogenicity and mitochondrial and nuclear restriction fragment length polymorphisms (RFLPs) (Bates et al. 1989; Jeng et al. 1990). The aggressive isolates were further subdivided into the Eurasian (EAN) and North American (NAN) subgroups (Brasier 1979).

To help prevent the spread of the fungus into healthy trees, several alternatives are being investigated for the early detection and identification of the fungus in susceptible elms.
One method examines elm cell membrane permeability by measuring electrolyte loss in response to treatment with the pathogen or with culture filtrates of the pathogen (Mezzetti et al. 1988; Otani et al. 1986). Increased membrane permeability was correlated with greater susceptibility to aggressive strains of $O$. ulmi in three elm species. These results support earlier findings (Richards and Takai 1984), where a similar correlation was noted following the treatment of resistant or susceptible elms with the toxin cerato-ulmin.

An approach which holds some promise for rapid automation and possible use in the field is the use of monoclonal antibodies specific to epitopes found only on aggressive isolates of O. ulmi (Dewey et al. 1989). Although antibody titer was low, some of the monoclonals have been used successfully to differentiate diseased elms from healthy ones with very little cross reactivity with the host tissue. When the mycelial extracts from aggressive and non-aggressive strains were compared using electrophoretic techniques, different patterns of soluble proteins were observed. In fact, 48 proteins were characteristic of either one of the two strains tested (Jeng 1986). These molecular techniques should increase the effectiveness of rapid detection of diseased trees and provide early intervention against DED.

Molecular genetic analysis. A chromosome linkage map of $O$. ulmi was developed from the analysis of a collection of mutants in order to better understand the biochemical genetics of the fungus (Bernier and Hubbes 1985, 1986). A crude linkage map was developed (Bernier and Hubbes 1986) which has been refined further (Bernier et al. 1987; Bernier and Hubbes 1990b). Additional studies led to the isolation of anatomical, auxotrophic, drug-resistant (Bernier and Hubbes 1990a), and low CU-producing mutants (Jeng et al. 1987). Inoculations of American elms with wild-type and mutant (low CU-producing) isolates may provide further evidence for the role of $\mathrm{CU}$ in the proliferation of the symptoms of DED (Jeng et al. 1987).

Plasmids have been described in several isolates of the fungus, although the correlation between the presence of these extrachromosomal elements and aggressiveness or pathogenicity has not been demonstrated 
(Takai et al. 1984).

\section{Host}

Plants possess several biochemical defense mechanisms to control the spread of pathogens. The best studied of the elm molecular defense mechanisms which respond to infection by $O$. ulmi is the accumulation of phytoalexin-like sesquiterpenes. These compounds, mansonones A, C, D, E, F, and G, were proposed to be involved with host defenses following their isolation from tissues of DED-susceptible American elms after exposure to aggressive or non-aggressive strains of O. ulmi (Dumas et al. 1983; Elgersma and Overeem 1971). Mansonones were elicited more effectively and accumulated to higher levels when American elms were infected with non-aggressive strains compared to similar inoculations with aggressive strains (Duchesne et al. 1985, 1990; Jeng etal. 1983). Mansonones $E$ and $F$ were the most prevalent of the phytoalexins elicited (Duchesne $e t$ al. 1985). However, no differences in mansonone production were observed when DED-resistant Ulmus pumila L. was treated with aggressive or non-aggressive isolates of $O$. ulmi (Duchesne et al. 1986). Mansonones also accumulated when non-aggressive strains of $O$. $u l m i$ were used in immunizing inoculations before treatment of susceptible elms with aggressive strains (Duchesne et al. 1984; Jeng et al.1983).

Comparisons of extracts from infected elms demonstrated that resistant elms accumulate mansonones $\mathrm{E}$ and $\mathrm{F}$ to concentrations greater than three times that found in susceptible American elms (Proctor and Smalley 1988). This increase in mansonone production in resistant elms occurred within three days of inoculation with the fungal pathogen and was followed by a return to levels of susceptible elms within 12 days. In order to determine the effect of these phytoalexins on the fungus itself, mansonones were isolated and applied in vitro to aggressive or non-aggressive strains of $O$. ulmi. These compounds significantly inhibited the growth of the fungus (Dumas et al. 1986; Wu et al. 1985) and mansonone $\mathrm{E}$ had the greatest fungistatic effect on $O . u$ lmi in vitro (Wu et al. 1989). The addition of proteins such as albumin to the culture medium served to protect the fungus from the fungistatic effects of mansonone E. These results present evidence for a general hydrophobic interaction between the hydrophobic residues of the protein and the phytoalexins (Wu et al. 1989).

Several recent reports suggest that the use of callus material may be an appropriate and practical medium for analyzing the interactions between $O$. ulmi and elms. The results of inoculations of calli from resistant and susceptible elms with $O$. ulmi or culture filtrates from the fungus demonstrated a correlation between the response of the callus material to the stimulus and the response of the elm, from which the callus was derived, to the same antagonist (Krause et al. 1988; Pijut et al. 1988, 1990a, 1990b; Schreiber et al. 1988; Sticklen et al. 1990). Mansonone accumulation in callus cultures of $U$. americana and $U$. pumila was correlated with resistance to DED (L.C. Duchesne et al., unpublished data; Szczegola et al. 1987).

Resistance can be induced when susceptible elms are pre-treated with spores from non-aggressive strains of $O$. ulmi before inoculation with an aggressive strain (Hubbes and Jeng 1981). This phenomenon has been associated with a greater accumulation of mansonones in susceptible elms after treatment with non-aggressive strains of the fungus than with aggressive strains (Duchesne $e t$ al. 1984), although it was also speculated that mansonone accumulation was not solely responsible for the phenomenon of induced resistance (Duchesne 1988; Dumas et al. 1986).

\section{Beetles}

A great deal of research has been conducted to understand the role of beetle attracting agents in the spread of Dutch elm disease. The attractants include 4-methyl--3-heptanol and (-)- $\alpha$-multistriatin, produced by the female elm bark beetles, and (-)- $\alpha$-cubebene, released from the host (Lanier 1983). The chemical structure of these agents is so specific that the $(+)$ stereoisomer of $\alpha$-multistriatin is no more effective as an attractant than control reagents (Elliot et al. 1979). These attractants have been used successfully to lure beetles into traps to reduce the spread of the fungus from diseased to healthy trees (Lanier 1989). Emphasis is now shifting toward the 
use of modern molecular techniques to control the spread of Dutch elm disease via the beetle vectors. Some polypeptide toxins, such as the Bacillus thuringiensis (BT) toxins, have been discovered to be specific in their pathogenicity toward lepidopteran, coleopteran and dipteran insects (Höfte and Whiteley 1989). Lepidopteran BT toxins are pathogenic to two species of elm bark beetle (Coleoptera: Scolytidae) and it will be interesting to see the effect of coleopteran-specific toxins on these beetles (Jassim et al. 1990). A coleopteranspecific BT toxin was also pathogenic toward elm leaf beetles (Hernstadt et al. 1986). As genes encoding these toxins become available, the next step may be to introduce these genes into susceptible elms to provide the elms with a measure of self-defense.

\section{Future trends and approaches}

The management of DED should be pursued using an integrated approach through the use of chemical means of disease protection; induction, identification, and genetic manipulation of the host's defense system; and the control of pathogen virulence (Hubbes 1988). Hopefully, this will lead to a longterm, well-balanced coexistence between the pathogen and its host (Hubbes 1988). One of the first steps toward accomplishing this goal will be to attain a better understanding of the interactions between the insect carrier, the host and the pathogen, from the introduction of the beetle-borne fungus to the failure of the host defense mechanisms. As we begin to learn the details of these interactions, the results will dictate strategies for controlling DED. We envision three avenues of research concerning each of the organisms involved in DED.

With the exception of transmission of DED through root grafts, the elm bark beetle is the sole carrier of the pathogen from diseased to healthy elms. Preventing the elm bark beetle from colonizing susceptible elms should greatly decrease DED. Direct methods such as the use of insecticides directly on trees or via pheromone-baited traps, are probably not the most efficient approaches although they have been useful in the past. However, a longterm approach which has the potential for a consistent impact on the beetle would be the use of biological control (Mazzone and Peacock 1985). One option is the use of entomopathogens such as bacteria, fungi, viruses or nematodes specific to the elm bark beetles. Finding such pathogens should be straightforward for entomologists but making sure that the selected pathogen is specific for the beetles may be more difficult. Another possibility involves the release of sterile male beetles. A similar approach using a large population of radiation-sterilized insects caused the virtual elimination of the screwworm fly (Cochliomyia hominivorax Coquerel) in the United States in 1962 (Bushland 1975; Davidson 1974). The use of pheromones in conjunction with these methods could grealty improve results by attracting swarms of female beetles to mate with the sterile males.

Biological control strategies should also be devised for the control of O. ulmi. The need for biological control originates from the failure of chemical fungicides to eradicate the pathogen without damaging trees (Karnosky 1979). The use of the d-factors could eventually serve as a natural control of $O$. ulmi (Brasier 1983, 1988; Webber 1987). Another option is the development and selection of dominant non-pathogenic, mating-type isolates of $O$. ulmi, followed by their release in nature to mate with highly aggressive isolates. However, the factors and mechanisms which confer aggressiveness and pathogenicity to the fungus are still not fully understood and clearly more work is needed before this strategy can be employed.

Understanding the molecular mechanisms of pathogenicity in DED is being emphasized by attempts to isolate the genes encoding cerato-ulmin in O.ulmi. A cDNA library is being screened with an antibody raised against CU (M. Hubbes, unpublished data). Since the amino acid sequence of $\mathrm{CU}$ is known, it may be possible to express $\mathrm{CU}$ from synthetic DNA in order to provide a resource for learning more about the mechanism of action of CU at the molecular level (Bolyard and Sticklen 1990). Efforts are currently underway to express CU in Escherichia coli (Migula) Castellani and Chalmers to determine what regions and residues of the molecule are responsible for its pathogenicity and specificity. Other approaches include the characterization of the mitochondrial and nuclear 
genomes of aggressive and non-aggressive isolates using various heterologous cDNA and genomic probes.

Other metabolites synthesized by $O$. ulmi are also under scrutiny, particularly elicitors produced by both aggressive and non-aggressive strains of the fungus. Recent work has established that these elicitors stimulate the production of mansonones, although at higher levels in $U$. americana than in $U$. pumila. These elicitors are small glycoproteins whose activity is increased when the carbohydrate moieties are removed with $B$-glucosidase. Higher elicitor activity was found in fungal cell wall extracts than in culture filtrates (Yang et al. 1989).

Assay systems using callus cultures are being used to demonstrate differences in levels of mansonone accumulation between DEDresistant and DED-susceptible elms. These results indicate that mansonone acculumation may be used as a selective marker for resistance to DED in callus cultures of elms (Szczegola et al. 1987). Callus cultures are also being used to test susceptible, resistant, and selected putatively resistant American elms by subjecting these cultures to media containing various concentrations of purified CU (Sticklen et al. 1990), which is similar to work conducted earlier by Pijut and her colleagues (Pijut 1988; Pijut et al. 1988, 1990a, 1990b). However, variations exist among callus lines within the same elm species suggesting that careful interpretation of the results of subsequent in vitro assays will be required (Szczegola-Derkacz 1988).

Finally, controlling DED via the elms may be possible. All attempts to sexually transfer DED resistance into American elm have been unsuccessful (Karnosky 1981; Redenbaugh et al. 1977; Sticklen et al. 1985, 1986) due in part to the incompatibility between the tetraploid American elm $(4 n=56)$ and diploid DEDresistant elms $(2 \mathrm{n}=28)$ (Redenbaugh et al. 1977 ) and to the inhibition of pollen germination and early pollen tube growth on stigmatic surfaces during sexual crosses (Ager and Guries 1982; Bob et al. 1986). This incompatibility is postulated to be mediated through a number of unknown physiological and anatomical factors (Pijut 1988). An alternative approach has been to select American elms for resistance to DED, such as the
American elm cultivars 'Delaware 2' and '8630' (Pijut 1988; Townsend and Schreiber 1975). When callus lines produced from these cultivars were compared to callus from a DED-susceptible American elm in culture media containing a crude filtrate of $O$. ulmi, 'Delaware 2' and '8630' were found to be resistant to the toxin in the culture (Pijut 1988, 1990a). Another group of selected DED-resistant American elms are from a controlled pollination between 'Delaware 2' and survivors of a second test group of over 60000 inoculated American elm seedlings, or between the survivors themselves (E. Smalley, unpublished data). One of the five selected elms from this group is being distributed by the Elm Research Institute as a DED-resistant elm, U. americana $\mathrm{cv}$. Liberty.

The failure of the breeding of DED resistance into American elms as well as difficulties in selecting naturally resistant variants, has prompted the use of alternative strategies such as cell and callus culture (Karnosky and Mickler 1986) which may also provide an opportunity for the eventual genetic engineering of elms (Bolyard et al. 1991b). The regeneration of American elms from juvenile tissue has been reported from hypocotyl-derived cell suspension cultures (Durzan and Lopushanski 1975), from axillary buds (Chalupa 1979), from hypocotyl-derived callus culture (Karnosky et al. 1982), and following the successful cryogenic preservation of American elm callus lines followed by subsequent shoot regeneration (Ulrich et al. 1984). Recently, cultures from mature leaves of American elms have been used to produce multiple shoots in media containing the cytokinins thidiazuron (Bolyard et al. 1991 a) and/or pyranyl benzyladenine (Bolyard et al. 1991c). This system has also been used to develop shoots from leaf cultures of several putatively DED-resistant American elms (Bolyard et al. 1991c) as well as from the DED-resistant elm Ulmus parvifolia Jacq. (Bolyard et al. 1991a). In an attempt to produce somatic hybrid plants between American elm and the DED-resistant hybrid Ulmus XPioneer elm (Townsend and Masters 1984), fusion callus lines were produced, although somatic hybrid plants have not been regenerated (Sticklen 1989, 1990). In addition, RFLP and dimer isozyme banding pattern differences between American and Pioneer elm cal- 
lus lines have been identified (Sticklen 1989).

Since the pathogen has co-evolved with the host, it should not be long (in evolutionary time) before the fungus evolves strains that are pathogenic to selected elms. Once the mechanisms of DED resistance are known, it may be possible to address the issue of the rapid mutagenesis of the pathogen to selected resistant elms. Clearly, if genes responsible for DED resistance are identified and isolated and if the metabolic pathways leading to resistance are elucidated, effective approaches for the development of resistance in susceptible elms will become available. Experiments are currently underway to devise strategies to identify DED resistance associated genes and isolate them via RFLP analyses using CDNA probes from putatively DED-resistant elms. If and when the DED resistance genes are available, these genes could be appropriately modified to circumvent the hypermutable pathogen and gene-transfer methods could be used to develop DED-resistant elms.

However, considering the long life cycle of elms, the techniques of vegetative regeneration via protoplast, cell, or tissue culture will have to be perfected before even the best gene-transfer system are successful. In addition to the utility of vegetative propagation for the genetic engineering of elms, these methods will immensely benefit current attempts in managing DED.

This work is dedicated to the memory of Dr. Shozo Takai for his steadfast investigation into the pathogenesis of Dutch elm disease. The authors would like to thank Drs. J. Sherald and F.W. Holmes for their assistance in our literature search. We also thank Drs. M. Hubbes, R. Jeng, W. Richards, E. Smalley, and G. Strobel for helpful discussion and criticism, and for sharing unpublished information. This work was supported by National Park Services of the Department of Interior (CA-3040-9-8001). This manuscript is from the Agricultural Experiment Station, College of Agriculture and Natural Resources, Michigan State University.

Ager, A.A., and R.P. Guries. 1982. Barriers to interspecific hybridization in Ulmus americana. Euphytica 31: 909-920.

Agrios, G.N. 1988. Plant Pathology, 3rd Edition. Academic Press, New York. 425 pp.

Bates, M.R., K.W. Buck, and C.M. Brasier. 1989. The use of nuclear and mitochondrial DNA polymorphisms to investigate the population genetics, epidemiology and evolution of Ophiostoma ulmi the causative agent of Dutch elm disease. J. Cell. Biochem. 13C: 112(Abstract).
Beckman, C.H. 1971. The plasticizing of plant cell walls and tylose formation. Physiol. Plant Pathol. 1: $1-10$.

Benhamou, N., G.B. Ouellette, J.G. Lafontaine, and J.R. Joly. 1985. Use of monoclonal antibodies to detect a phytotoxic glycopeptide produced by Ophiostoma ulmi, the Dutch elm disease pathogen. Can. J. Bot. 63: 1177-1184.

Bernier,L., and M. Hubbes. 1985. Artificial induction of mutations in Ophiostoma ulmi, the causal agent of Dutch elm disease. Can. J. Plant Pathol. 7: 442 (Abstract).

Bernier, L., and M. Hubbes. 1986. Induction, characterization and mapping of mutation in Ophiostoma ulmi. Can. J. Plant Pathol. 8: 347-348 (Abstract).

Bernier, L., and M. Hubbes. 1990a. Mutations in Ophiostoma ulmi by N-methyl-N'-nitro-N-nitrosoguanidine. Can. J. Bot. 68: 225-231.

Bernier, L., and M. Hubbes. 1990b. Meiotic analysis of induced mutations in Ophiostoma ulmi. Can. J. Bot. 68: 232-235.

Bernier, L., R.S. Jeng, and M. Hubbes. 1987. Genetics of Ophiostoma ulmi, the causal agent of Dutch elm disease. Can. J. Plant Pathol. 9: 273 (Abstract).

Bob, C.F., B.L. Redmond, and D.F. Karnosky. 1986. On the nature of intra- and interspecific incompatibility in Ulmus. Am. J. Bot. 73: 465-474.

Bolyard, M.G., and M.B.Sticklen. 1990. Strategies for producing non-toxic variants of cerato-ulmin, a Dutch elm disease toxin, using synthetic DNA. J. Cell. Biochem. Suppl. 14E: R204 (Abstract).

Bolyard, M.G., C. Srinivasan, J. Cheng, and M.B. Sticklen. 1991a. In vitro propagation of American and Chinese elm from leaf explants. HortScience (In press).

Bolyard, M.G., R.K.Hajela, and M.B.Sticklen.1991b. Microprojectile and Agrobacterium-mediated transformation of Pioneer elm. J. Arboric. 17: 34-37.

Bolyard, M.G., C. Srinivasan, and M.B. Sticklen. 1991c. Shoot regeneration system for DED susceptible and putatively resistant American elms. J. Cell. Biochem. Suppl. 15A: A202 (Abstract).

Bonsen, K.J.M., R.J. Scheffer, and D.M. Elgersma. 1985. Barrier zone formation as a resistance mechanism of elms to Dutch elm disease. IAWA Bull. 6: 71-77.

Brasier, C.M. 1979. Dual origin of recent Dutch elm disease outbreaks in Europe. Nature 281:78-80.

Brasier, C.M. 1983. A cytoplasmically transmitted disease of Ceratocystis ulmi. Nature 305: 220-223.

Brasier, C.M. 1986. The d-factor in Ceratocystis ulmi - Its biological characteristics and implications for Dutch elm disease. Pages 177-208 in K.W. Buck (ed.), Fungal virology. CRC Press, Boca Raton, FL.

Brasier, C.M. 1988. Rapid changes in genetic structure of epidemic populations of Ophiostoma ulmi. Nature 332: 538-541.

Brasier, C.M. and J.N. Gibbs. 1975. Variation in Ceratocystis ulmi: Significance of the aggressive and non-aggressive strains. Pages 53-66 in Proc. IUFRO Conference. St. Paul, MN, USA, Sept. 1973.

Brasier, C.M., and J.F. Webber. 1987. Positive correlations between in vitro growth rate and pathogenesis in Ophiostoma ulmi. Plant Pathol. 36: 462-466.

Bushland, R.C. 1975. Screw-worm research and eradication. Bull. Entomol. Soc. Am. 21:23-26. 
Chalupa, V. 1979. In vitro propagation of some broadleaved forest trees. Inst. For. Czech. 9: 159-170.

Claydon, N., D.M. Elgersma, and J.F. Grove. 1980. The phytotoxicity of some phenolic metabolic products of Ophiostoma ulmi to Ulmus sp. Neth.J.Plant Pathol. 86: 229-237.

Davidson, G. 1974. Genetic control of insect pests. Academic Press, London and New York. 158 pp.

de Hoog, S., and R.J. Scheffer. 1984. Ceratocystis vs. Ophiostoma: a reappraisal. Mycologia 76: 292-299.

Desrochers, P., N. Benhamou, R. Gardiner, and G.B. Ouellette. 1987. Inhibition of Ophiostoma ulmi by an ascomycete. Can. J. Plant Pathol. 9: 276 (Abstract).

Dewey, F.M., C.J. Munday, and C.M. Brasier. 1989. Monoclonal antibodies to specific components of the Dutch elm disease pathogen Ophiostoma ulmi. Plant Pathol. 38: 9-20.

Duchesne, L.C. 1988. Resistance mechanisms to Dutch elm disease: A review. Nat. Can. 115: 163-167.

Duchesne, L.C., R.S. Jeng, and M. Hubbes. 1984. Effect of Ceratocystis ulmi strain aggressiveness on phytoalexin accumulation in Ulmus americana. Can. J. Plant Pathol. 6: 261 (Abstract).

Duchesne, L.C., R.S. Jeng, and M. Hubbes. 1985. Accumulation of phytoalexins in Ulmus americana in response to infection by a nonaggressive and an aggressive strain of $O$ phiostoma ulmi. Can. J. Bot. 63:678-680.

Duchesne, L.C., M. Hubbes, and R.S. Jeng. 1986. Mansonone E and F accumulation in Ulmus pumila resistant to Dutch elm disease. Can. J. For. Res. 16 : 410-412.

Duchesne, L.C., R.S. Jeng, M. Hubbes, and M.B. Sticklen. 1990. Accumulation of mansonones E and $\mathrm{F}$ in seedlings of Ulmus americana in response to inoculation with Ophiostoma ulmi. Struct. Func. Trees 4: 187-190.

Dumas, M.T., G.M. Strunz, M. Hubbes, and R.S. Jeng. 1983. Isolation and identification of six mansonones from Ulmus americana infected with Ceratocystis ulmi. Experientia 39: 1089-1090.

Dumas, M.T., G.M. Strunz, M. Hubbes, and R.S. Jeng. 1986. Inhibition of Ceratocystis ulmi by mansonones A, C, D, E, F, and G isolated from Ulmus americana. Eur. J. For. Pathol. 16:217-222.

Durzan, D.J., and S.M. Lopushanski. 1975. Propagation of American elm via cell suspension culture. Can. J. For. Res. 5: 273-277.

Elgersma, D.M. 1973. Tylose formation in elms after inoculation with Ceratocystis ulmi, a possible resistance mechanism. Neth. J. Plant Pathol. 79: 218 220.

Elgersma, D.M., and H.J. Miller. 1977. Tylose formation in elms after inoculation with an aggressive or a non-aggressive strain of Ophiostoma ulmi or with a non-pathogen to elms. Neth. J. Plant Pathol. 83: 241-243.

Elgersma, D.M., and J.C. Overeem. 1971. The relation of mansonones to resistance against Dutch elm disease and their accumulation as induced by several agents. Neth. J. Plant Pathol. 79: 218-220.

Elliot. W.J., G. Hromnak, J. Fried, and G.N. Lanier. 1979. Synthesis of multistriatin enantiomers and their action on Scolytus multistriatus (Coleoptera: Scolytidae). J. Chem. Ecol. 5: 279-287.
Fox, J.L. 1987. Assessing the Dutch elm disease backlash. Bio/Technology 5: 1002-1003.

Gibbs, J.N., and C.M. Brasier. 1973. Correlation between cultural characters and pathogenicity in Ceratocystis ulmi from Britain, Europe, and America. Nature 241:381-383.

Gregory, G.F., L.R. Schreiber, and J. Ichida. 1984. Microorganisms antagonistic to or producing antibiotic inhibitory to Ceratocystis ulmi. Phytopathology 74: 804-805

Gregory, G., R. Lewis, L. Schreiber, N. Roberto, J. Ichida, and J. Thomas. 1986. A Pseudomonas species isolated from live oaks antagonistic to several tree pathogens. Phytopathology 76: 652-653.

Hall, R., and W.E. MacHardy. 1981. Water relations. Pages 255-298 in M.E. Mace, A.A. Bell, and C.H. Beckman (eds.), Fungal wilt diseases of plants. Academic Press, New York.

Harrison, L.A. 1989. Purification and characterization of pseudomycin, a phytotoxin and antimycotic produced by Pseudomonas syringae. M.Sc. thesis, Department of Plant Pathology, Montana State University, Bozeman.

Herrnstadt, C., G.G. Soares, E.R. Wilcox, and D.L. Edwards. 1986. A new strain of Bacillus thuringiensis with activity against coleopteran insects. Bio/ Technology 4: 305-308.

Hoch, J.G., S.M. Tavantzis, R.J. Campana, and S.L. Anagnostakis. 1985. Evaluation of the presence of double-stranded RNA in Ceratocystis ulmi. Can.J. Bot. 63: 297-300.

Höfte, H., and H.R. Whiteley. 1989. Insecticidal crystal proteins of Bacillus thuringiensis. Microbiol. Rev. 53: 242-255.

Hubbes, M. 1988. Pathogen virulence and host reaction in Dutch elm disease. Nat. Can. 115: 157-161.

Hubbes, M., and R.S. Jeng. 1981. Aggressiveness of Ceratocystis ulmi strains and induction of resistance in Ulmus americana. Eur. J. For. Pathol. 11:257. 264.

Ipsen, J.D., and Y.J. Abul-Hajj. 1982. Fluorescent antibody technique as a means of localizing Ceratocystis ulmi toxins in elm. Can. J. Bot. 60: 724-729.

Jassim, H.K., H.A. Foster, and C.P. Fairhurst. 1990. Biological control of Dutch elm disease: Bacillus thuringiensis as a potential control agent for $\mathrm{Sco}$ lytus scolytus and S. multistriatus. J. Appl. Bacteriol. 69: 563-568.

Jeng, R.S. 1986. Analytical electrofocusing and twodimensional electrophoresis of proteins extracted from the mycelia of aggressive and nonaggressive strains of Ophiostoma ulmi. Can. J. Bot. 64: 2073 2081.

Jeng. R.S., A.C. Alfenas, M. Hubbes, and M. Dumas. 1983. Presence and accumulation of fungitoxic substances against Ceratocystis ulmi in Ulmus americana: possible relation to induced resistance. Eur. J. For. Pathol. 13:239-244.

Jeng, R.S., L. Bernier, and A.M.Svircev. 1987. Low cerato-ulmin-producing mutants from an aggressive isolate of Ophiostoma ulmi, the causal agent of Dutch elm disease. Can. J. Plant Pathol. 9: 280 (Abstract). 
Jeng, R.S., L.C. Duchesne, M. Sabourin, and M. Hubbes. 1990. Mitochondrial DNA restriction fragment length polymorphisms of aggressive and nonaggressive isolates of Ophiostoma ulmi. Mycol. Res. (In press).

Karnosky, D.F. 1979. Dutch Elm Disease: A review of the history, environmental implications, control, and research needs. Environ. Conserv. 6: 311-322.

Karnosky, D.F. 1981. Potential for forest tree improvement via tissue culture. BioScience 31: 114-120.

Karnosky, D.F., and A. Mickler. 1986. Elms (Ulmus spp.). Pages 326-340 in Y.P.S. Bajaj (ed.), Biotechnology in agriculture and forestry, Vol. 1: Trees 1. Springer-Verlag, Berlin and Heidelberg.

Karnosky, D.F., R.A. Mickler, and D.D. Lange. 1982. Hormonal control of shoot and root induction in hypocotyl callus cultures of American elm. In Vitro 18:275 (Abstract)

Krause, C.R., J.M. Ichida, L.R. Schreiber, and G.F. Gregory. 1987. Morphological and cytological effects on Ceratocystis ulmi of an antifungal antibiotic produced by Bacillus subtilis. Phytopathology 77: 1771 (Abstract).

Krause, C.R., J.M. Ichida, L.R. Schreiber, and S. Domir. 1988. Host-parasite relationships of elm calli challenged with Ceratocystis ulmi. Phytopathology 78: 1610 (Abstract).

Lam, B.S., G.A. Strobel, L.A. Harrison, and S.T. Lam. 1987. Transposon mutagenesis and tagging of fluorescent $P$ seudomonas: Antimycotic production is necessary for control of Dutch elm disease. Proc. Nat. Acad. Sci. USA 84: 6447-6451.

Landis, W.R., and J.H. Hart. 1972. Physiological changes in pathogen free tissue of Ulmus americana induced by Ceratocystis ulmi. Phytopathology 62: 909-913

Lanier, G.N. 1983. Integration of visual stimuli, host odorants, and pheromones by bark beetles and weevils in locating and colonizing host trees. Pages 161-171 in S. Ahmad (ed.), Herbivorous insects. Academic Press, New York.

Lanier, G.N. 1989. Trap trees for control of Dutch elm disease. J. Arboric. 15: 105-111.

May, C. 1930. Dutch Elm Disease in Ohio. Science 72: 142-143.

Mazzone, H.M., and J.W. Peacock. 1985. Prospects for biological control of Dutch elm disease - Biological considerations. J. Arboric. 11:285-292.

Mezzetti, B., L. Mittempergher, and P. Rosati. 1988. Ophiostoma ulmi metabolites and elm cell membrane permeability. Possible use in early tests of resistance. Eur. J. For. Pathol. 18:77-84.

Murdoch, C.W., R.J. Campana, and J. Hoch. 1984. On the biological control of Ceratocystis ulmi with Pseudomonasfluorescens. Phytopathology 74: 805.

Nordin, J.H., and G.A.Strobel. 1981. Structural and immunochemical studies on the phytotoxic peptidorhamnomannan of Ceratocystis ulmi. Plant Physiol. 67: 1208-1213.

Nordin, J.H., T.L. Mason, L.L. Smith, P.A. Willmann, W.C. Richards, and S. Takai. 1987. Use of an enzyme-linked immunosorbent assay with murine ascitic antibodies to screen microorganisms for production of cerato-ulmin, a toxin of Ceratocystis ulmi. Phytopathology 77:96-100.
Otani, H., S. Takai, W.C. Richards, K. Kohmoto, and $S$. Nishimura. 1986. Effect of cerato-ulmin (CU) on electrolyte loss from elm leaf cells. Ann. Phytopathol. Soc. Jpn 52: 133 (Abstract).

Ouellette, G.B. 1978a. Unusual cell wall layers in elm parenchyma of secondary xylem. Can. J. Bot. 56: 2109-2113.

Ouellette, G.B. 1978b. Fine structural observations on substances attributable to Ceratocystis ulmi in American elm and aspects of host cell disturbances. Can. J. Bot. 56: 2550-2556.

Ouellette, G.B. 1978c. Ultrastructural observations on pit membrane alterations and associated effects in elm xylem tissues infected by Ceratocystis ulmi. Can. J. Bot. 56: 2567-2588.

Ouellette, G.B. 1980. Occurrence of tyloses and their ultrastructural differentiation from similarly configured structures in American elm infected by Ceratocystis ulmi. Can. J. Bot. 58: 1056-1073.

Pearce, G.T., W.E. Gore, R.M. Silverstein, J.W. Peacock, R.A. Cuthbert, G.N. Lanier, and J.B. Simone. 1975. Chemical attractants for the smaller European elm bark beetle Scolytus multistriatus (Coleoptera: Scolytidae). J. Chem. Ecol. 1: 115-124.

Pijut, P.M. 1988. Effects of culture filtrates of $C$ eratocystis ulmi on growth and ultrastructure of in vitro cultured Ulmus americana. Ph. D. thesis, Department of Horticulture, Ohio State University, Columbus.

Pijut, P.M., R.D. Lineberger, S.C. Domir, and L.R. Schreiber. 1988. Response of elm callus to culture filtrate of Ceratocystis ulmi and correlation with whole plant disease reaction. HortScience 23: 787 (Abstract).

Pijut, P.M., S.C. Domir, R.D. Lineberger, and L.R. Schreiber. 1990a. Use of culture filtrates of Ceratocystis ulmi as a bioassay to screen for disease tolerant Ulmus americana. Plant Sci. 70: 191-196.

Pijut P.M., R.D. Lineberger, S.C. Domir, J.M. Ichida, and C.R. Krause. 1990b. Ultrastructure of cells of Ulmus americana cultured in vitro and exposed to the culture filtrate of Ceratocystis ulmi. Phytopathology 80: 764-767.

Proctor, R.H., and E.B. Smalley. 1988. Localized accumulation of mansonones $\mathrm{E}$ and $\mathrm{F}$ in elms following inoculations with Ophiostoma ulmi. Can. J. Plant Pathol. 10:371 (Abstract).

Pusey, P.L., and C.L. Wilson. 1982. Detection of double-stranded RNA in Ceratocystis ulmi. Phytopathology 72: 423-428.

Redenbaugh, M.K., D.F. Karnosky, and R.D. Westfall. 1977. In vitro culture of American elm anthers, Pages 154-163 in Proceedings of the 25th Northwest Forest Tree Improvement Conference. University of Maine, Orono.

Richards, W.C., and S. Takai. 1984. Characterization of the toxicity of cerato-ulmin, the toxin of Dutch elm disease. Can.J.Plant Pathol. 6: 291-298.

Rioux, D., and G.B. Ouellette. 1989. Light microscope observations of histological changes induced by Ophiostoma ulmi in various nonhost trees and shrubs. Can. J. Bot. 67: 2335-2351.

Roberts, L. 1987. New questions in Strobel case. Science 237: 10097-10098. 
Rogers, H.J., K.W. Buck, and C.M. Brasier. 1986a. Transmission of double-stranded RNA and a disease factor in Ophiostoma ulmi. Plant Pathol. 35: 277 287.

Rogers, H.J., K.W. Buck, and C.M. Brasier. 1986 b. The molecular nature of the D-factor in Ceratocystis ulmi. Pages 209-219 in K.W. Buck (ed.), Fungal virology. CRC Press, Boca Raton, FL.

Rogers, H.J., K.W. Buck, and C.M. Brasier. 1987. A mitochondrial target for double-stranded RNA in diseased isolates of the fungus that causes Dutch elm disease. Nature 329: 558-560.

Scheffer, R.J. 1982. A phytotoxic glycopeptide produced by Ophiostoma ulmi in several elm species and clones. Pages 215-223 in E.S. Kondo, Y. Hiratsuka, and W.B.G. Denyer (eds.), Proceedings of the Dutch Elm Disease Symposium and Workshop. Manitoba Department of Natural Resources, Winnipeg, Manitoba, Canada.

Scheffer, R.J. 1989. P seudomonas for biological control of Dutch elm disease. III. Field trials at various locations in the Netherlands. Neth. J. Plant Pathol. 95: 305-318.

Scheffer, R.J. and D.M. Elgersma. 1981. Detection of a phytotoxic glycopeptide produced by Ophiostoma ulmi in elm by enzyme-linked immunospecific assay (ELISA). Physiol. Plant Pathol. 18: 27-32.

Scheffer, R.J., H.M. Heybroek, and D.M. Elgersma. 1980. Symptom expression in elms after inoculation with combinations of an aggressive and non-aggressive strain of Ophiostoma ulmi. Neth. J. Plant Pathol. $86: 315-317$

Scheffer, R.J., J.I. Liem, and D.M. EIgersma. 1987. Production in vitro of phytotoxic compounds by non-aggressive and aggressive isolates of Ophiostoma ulmi, the Dutch elm disease pathogen. Physiol. Mol. Plant Pathol. 30: 321-335.

Schreiber, L.R., and A.M. Townsend. 1976. Variability in aggressiveness, recovery, and cultural characteristics of isolates of Ceratocystis ulmi. Phytopathology 66: 239-244.

Schreiber, L.R., S. Domir, J. Ichida, and C. Krause. 1988. Factors affecting host-pathogen interactions between elm callus cultures and Ceratocystis ulmi. Phytopathology 78: 1618.

Sherald, J.L., and H.D. Sisler. 1972. Selective inhibition of antimycin A-insensitive respiration in Ustilago maydis and Ceratocystis ulmi. Plant Cell Physiol. 13: 1039-1052.

Shi, J.L., and C.M. Brasier. 1986. Experiments on the control of Dutch elm disease by injection of Pseudomonas species. Eur. J. For. Pathol. 16: 280-292.

Shigo, A.L. 1984. Compartmentalization: a conceptual framework for understanding how trees grow and defend themselves. Annu. Rev. Phytopathol. 22: 189-214.

Singh, D. and E.B.Smalley. 1969a. Changes in amino acid and sugar constituents of the xylem sap of the American elm following inoculation with Ceratocystis ulmi. Phytopathology 59:891-896.

Singh, D. and E.B.Smalley. 1969b. Nitrogenous and carbohydrate compounds in the xylem sap of Ulmaceae species varying in resistance to Dutch elm disease. Can. J. Bot. 47: 335-339.
Stevenson, K.J., and S. Takai. 1982. Structural studies on cerato-ulmin - a wilting toxin of Dutch elm disease fungus, Ceratocystis ulmi. Pages 178-194 in E.S.Kondo, Y.Hiratsuka, and W.B.G. Denyer(eds.), Proceedings of the Dutch Elm Disease Symposium and Workshop. Manitoba Department of Natural Resources, Winnipeg, Manitoba, Canada.

Stevenson, K.J., J.A. Slater, and S. Takai. 1979. Cerato-ulmin - a wilting toxin of Dutch elm disease fungus. Phytochemistry 18: 235-238.

Sticklen, M.B. 1989. Restriction fragment length polymorphism for confirmation of hybridity of elm fusion partners. 86th Annual Meeting of Am. Soc. Hortic. Sci.pp. 112. June, 1989 (Abstract).

Sticklen, M.B. 1990. Somatic hybridization and evaluation of RFLP and dimer isozyme molecular markers for confirmation of hybridity of elm fusion products. Proc. IUFRO. Ames, Iowa, October, 1988 (In press).

Sticklen, M.B., R.D. Lineberger, and S.C. Domir. 1985. Isolation and culture of protoplasts of Ulmus x 'Homestead'. Plant Sci. 41: 117-120.

Sticklen, M.B., S.C. Domir, and R.D. Lineberger. 1986. Shoot regeneration from protoplasts of Ulmus x 'Pioneer'. Plant Sci. 47: 29-34.

Sticklen, M.B., M.G. Bolyard, and J. Cheng. 1990. Methods for in vitro selection of Dutch elm disease resistant American elms and expression of synthetic DNA encoding a Dutch elm disease toxin in E. coli. Proceedings of the International Energy Agency Symposium on the Exchange of Genetic Material. Geraadsbergen, Belgium. Sept. 9-14, 1990 (In press).

Strobel, G.A., N. Van Alfen, K.D. Hapner, M. McNeil, and P. Albersheim. 1978. Some phytotoxic glycopeptides from Ceratocystis ulmi, the Dutch elm disease pathogen. Biochim. Biophys. Acta 538: 60-75.

Svircev, A.M., R.S. Jeng, and M. Hubbes. 1988. Detection of cerato-ulmin on aggressive isolates of Ophiostoma ulmi by immunocytochemistry and scanning electron microscopy. Phytopathology 78 : 322-327.

Szczegola, M., R. Jeng, and M. Hubbes. 1987. Mansonone induction by Ophiostoma ulmi in callus cultures of elm species. Can. J. Plant Pathol. 9: 286 (Abstract).

Szczegola-Derkacz, M. 1988. Induction of mansonones by Ophiostoma ulmi in callus cell lines of Ulmus americana and Ulmus pumila. M. Sc. thesis, Faculty of Forestry, University of Toronto, Toronto.

Takai, S. 1974. Pathogenicity and cerato-ulmin production in Ceratocystis ulmi. Nature 252: 124-126.

Takai, S. 1989. Host specific factors in Dutch elm disease. Page 75-96 in K. Kohmoto and R.D. Durbin (eds.), Host Specific Toxins: Recognition and Specificity Factors in Plant Disease. Sogo Printing Co., Ltd., Tottori, Japan.

Takai, S., W.C. Richards, and K.J. Stevenson. 1983. Evidence for the involvement of cerato-ulmin, the Ceratocystis ulmi toxin, in the development of Dutch elm disease. Physiol. Plant Pathol. 23: 275-280.

Takai, S., T. Iizuka, and W. Richards. 1984. Discovery of plasmids in Ceratocystis ulmi. Phytopathology 74: 833 (Abstract). 
Townsend, A.M., and W.O. Masters. 1984. 'Pioneer' elm. HortScience 19: 900.

Townsend, A.M., and L.R. Schreiber. 1975. Recent progress in breeding and selection of elms. Proc. Ninth Central States For. Tree Improvement Conf. 9: 25-28.

Ulrich, J.M., R.A. Mickler, B.J. Finkle, and D.F. Karnosky. 1984. Survival and regeneration of American elm callus cultures after being frozen in liquid nitrogen. Can. J. For. Res. 14: 750-753.

Van Alfen, N.K. 1989. Reassessment of plant wilt toxins. Annu. Rev. Phytopathol. 27: 533-550.

Webber, J.F. 1987. Influence of the $\mathrm{d}^{2}$ factor on survival and infection by the Dutch elm disease pathogen Ophiostoma ulmi. Plant Pathol. 36: 531-538.
Webber, J.F. 1988. Impact of D-factor mycoviruses on infection by the elm pathogen Ophiostoma ulmi. Phytopathology 78: 1593 (Abstract).

Wu, W.D., R.S. Jeng, and M. Hubbes. 1985. Toxic effects of mansonones on Ophiostoma ulmi. Can.J. Plant Pathol. 7: 450.

Wu, W.D., R.S. Jeng, and M. Hubbes. 1989. Toxic effects of elm phytoalexin mansonones on Ophiostoma ulmi, the causal agent of Dutch elm disease. Eur. J. For. Pathol. 19: 343-357.

Yang, D., R.S. Jeng, and M. Hubbes. 1989. Mansonone accumulation in elm callus induced by elicitors of Ophiostoma ulmi, and general properties of elicitors. Can. J. Bot. 67: 3490-3497. 